\title{
Increasing efficiency of composite thermal insulation foam concretes
}

\author{
Valery Stanislavovich Lesovik \\ Institute of Architecture and Construction \\ Belgorod State Technological University named after \\ V.G.Shoukhov \\ Belgorod, Russia \\ Victor Mikhailovich Vorontsov \\ Institute of Architecture and Construction \\ Belgorod State Technological University named after \\ V.G.Shoukhov \\ Belgorod, Russia \\ Evgeny Sergeyevich Glagolev \\ Institute of Architecture and Construction \\ Belgorod State Technological University named after \\ V.G.Shoukhov \\ Belgorod, Russia
}

\begin{abstract}
The paper describes the development of composite binders with low water demand, obtained by intergrinding Portland cement, Muroplast hyperplasticizer, and tailings of magnetic separation of jaspilites from the Kursk Magnetic Anomaly. The obtained composite binders possess high strength properties after steam curing. The modifying effect of tailings of wet magnetic separation of jaspilites proved to be highly efficient. Composite optimum content binders (with strictly fixed amount of modifier and its specific surface area) were used to obtain outof-autoclave curing foam concrete with physical and mechanical properties that allow one to recommend the obtained product as a structural thermal insulation material. Scanning electron microscopy was used to study the foam concrete's pore structure and the distribution of pores and interpore walls across the volume of the material.
\end{abstract}

Keywords-composite binder, Muroplast hyperplasticizer, jaspilite magnetic separation tailings, Kursk Magnetic Anomaly, thermal insulation foam concrete, pore structure

\section{INTRODUCTION}

The major concern of scientists from all over the world is creating an environment comfortable for humans and reducing the energy intensity of producing composite materials. In the recent years, a new area of research has been formed: the architectural geonics, which implies using natural inorganic objects as prototypes for designing objects of architecture, street furniture, interior design, etc. This new field of research does not only deal with practical issues of organizing human environment, designing structural elements, forms and spaces, but also facilitates the improvement of people's emotional state, promoting creativity, harmonizing human functions and

\author{
Daniil Dmitrievich Pomochnicov \\ Institute of Architecture and Construction \\ Belgorod State Technological University named after \\ V.G.Shoukhov \\ Belgorod, Russia
}

\author{
Vasiliy Vasilievich Voronov \\ Institute of Architecture and Construction \\ Belgorod State Technological University named after \\ V.G.Shoukhov \\ Belgorod, Russia
}

\author{
Aleksandr Anatolevich Volodchenko \\ Institute of Architecture and Construction \\ Belgorod State Technological University named after \\ V.G.Shoukhov \\ Belgorod, Russia \\ naukavs@mail.ru
}

emotional associations, and generally optimizing the "humanmaterial-environment" triad [1-3].

Environmental protection and harmonization of the "human-material-environment" triad require the design of new efficient, long-lasting and environmentally friendly building materials.

Some of the major lines of research these days are energy conservation, sustainable natural resource management, and development of technologies for producing "green" composites, which is especially important for building materials science today.

In order to increase the range of wall materials, it is proposed using energy-saving aluminosilicate raw material with high free internal energy. The distinguishing feature of this raw material is its substantial difference from the traditionally used rock in the mineral composition and structure. The intensity of geological surveys has decreased in the recent $15-20$ years. There is virtually no increment of nonmetallic raw material reserves. The coming 10-20 years may leave us without traditional raw materials for the building materials industry.

One of the main performance indicators of any technology is the degree of feedstock conversion into useful product. However, in reality, a significant proportion of the feedstock is turned into tailings, which are most commonly sent to dump sites, significantly damaging the economy and environment.

Advancement of the modern minerals technology is unthinkable without integrated processing, where the entire material is processed into goods, thus eliminating the 
difference between the "main" product and the "by"-product. One of the main purposes of the integrated use of rock is using it to obtain building materials.

The growing pace of civil, industrial, transportation, and other areas of construction have led to accelerated development of the building material production industry. This industry is one of the primary energy consumers. Producing the required energy requires a lot of crude hydrocarbons, which burning emits large amounts of carbon dioxide and other contaminants into the atmosphere, thus negatevely affecting the biosphere. The building materials industry consumes approximately one-third of the world's energy consumption and produces $36 \%$ of carbon dioxide $\left(\mathrm{CO}_{2}\right)$ emissions. Statistics indicates that in 2012, global $\mathrm{CO}_{2}$ emissions amounted to $34 \mathrm{bn}$. tons and exceeded the 1990 values by $50 \%$. According to the data disclosed at the International Economic Platform for Renewable Energies (IWR) in Münster, if the current trend persists, by 2020 the volume of global $\mathrm{CO}_{2}$ emissions will increase by $20 \%$ and amount to $40 \mathrm{bn}$. tons. In contrast, in 1990 global $\mathrm{CO}_{2}$ emissions barely reached $22.7 \mathrm{bn}$. tons.

In order to curtail greenhouse gas emissions, it is necessary to completely reconsider industrial processes and choose the way of environmentally friendly production, which implies the use of modern "green" technologies that allow one to both preserve the environment and provide mankind with comfortable living conditions. Unfortunately, many new production plants are still built to ensure the performance characteristics of their main product only, leaving the rest without due attention. The goal of reducing the negative impact on the environment and conserving fuel resources requires working towards reducing energy consumption by producing building composites of a new generation.

In the recent years, strict requirements have been imposed thermal insulation of buildings and energy conservation during their usage.

Energy conservation is one of the most important contemporary issues in the Russian Federation, because natural resources are not unlimited and their prices grow, while they are being inefficiently consumed in large quantities. One-third of all exctracted natural fuel is used for heating of buildings and other structures, and up to 30-35\% of heat is lost into the environment. Heating $1 \mathrm{~m}^{2}$ in Russia requires $500 \mathrm{kWh}$, which is two times as much as Germany and three times as much as in the Nordic countries. Given the most efficient heating, energy consumption can be reduced to $60 \mathrm{kWh}$ per $1 \mathrm{~m}^{2}$, which means that the energy requirements can be reduced 8 times.

The wall materials that used to be traditional (sand-lime and ceramic brick, clay blocks, porous aggregate lightweight concretes, etc.) have become less significant, because with the 3-3.5-time increase of thermal resistance, walls made of brick with the density of $1500 \mathrm{~kg} / \mathrm{m}^{3}$ need to be thickened from 510-640 to $1000-1200 \mathrm{~mm}$, and walls made of expanded clay concrete with the density of $450 \mathrm{~kg} / \mathrm{m}^{3}$ need to be thickened from 390 to $500-700 \mathrm{~mm}$, which is ecocnomically inefficient. In this regard, wall assemblies made of highly efficient and long-lasting structural thermal insulation materials gain increased importance. One of the materials that have demonstrated high performance in use is the non-autoclaved aerated concrete [4-8].

Single-layer aerated concrete walls are simple in design, have low labour and energy intensity, high fire resistance and longevity, possess the necessary air- and waterproofing properties, and are environmentally friendly. Aerated concrete has broad range of sources of raw materials and can be used to erect monolithic, block, and panel walls.

The out-of-autoclave technology is low-energy intensive, zero waste and is characterized by the environmental friendliness of the end product and the possibility to use a wide range of cements and concrete modifiers, which allow to implement adjustable processing techniques, stable high quality of aerated concretes that increases with time, all at lower costs of production.

Aerated concretes are broadly used in various areas of modern building industry due to the specifics of its porous structure and, respectively, the wide variety of its functional possibilities. In particular, aerated concretes' bearing capacity at their normal density is sufficient for manufacturing building envelopes, walls, floor elements, and load-bearing elements for low-rise building.

High thermal insulation parameters, fire resistance, heat and water capacity condition the unique combination of all the advantages inherent in traditional building materials in just one material. Furthermore, low density facilitates the decrease of load upon the foundation and ensures high earthquake resistance of buildings and structures erected using aerated concretes.

Aerated concrete is generally used to manufacture building envelopes (external and internal walls, floors, lintels), which together must meet the requirements to their bearing capacity and longevity, thermal resistance, soundproofing, fire resistance, water-, damp- and airproofing, as well as to the requirements to the energy, costs, and labor necessary to produce them.

The leading position in the range of aerated concrete products belongs to producing unreinforced articles such as small and large masonry blocks. From the perspective of laying, aerated concrete blocks are highly efficient wall materials. Laying a block with the size of $200 \times 250 \times 600 \mathrm{~mm}$ and the density of $600 \mathrm{~kg} / \mathrm{m}^{3}$ (with the mass of $21 \mathrm{~kg}$ ) corresponds to simultaneous laying of 14 standard bricks (1 $\mathrm{m}^{3}$ of aerated concrete blocks equals 1000 pcs. of solid brick). Resolving the issues of building in Russia, and, above all, the recently intensified problem of cheap high-quality housing, it is necessary to increase the production of aerated concretes, which will allow one to significantly reduce the resource intensity of both building and upkeep. Table I shows the forecast increase rate of aerated concrete production in Russia, according to which the volume of autoclaved aerated concrete 
exceeds the volume of non-autoclaved concrete article manufacturing two to one.

TABLE I. FORECAST RATES OF THE INCREASE OF AERATED CONCRETE PRODUCTION IN RUSSIA.

\begin{tabular}{|c|c|c|c|c|c|c|}
\hline \multirow{2}{*}{$\begin{array}{l}\text { Aerated concrete } \\
\text { production, } \mathbf{m n} . \mathbf{~ m}^{3}\end{array}$} & \multicolumn{6}{|c|}{ Years } \\
\hline & 2015 & 2016 & 2017 & 2018 & 2019 & 2020 \\
\hline Autoclaved & 10 & 11 & 12 & 13 & 14 & 15 \\
\hline Non-autoclaved & 5.0 & 5.6 & 6.2 & 6.8 & 7.4 & 8.0 \\
\hline $\begin{array}{l}\text { Total per } 1000 \text { persons, } \\
\mathrm{m}^{3}\end{array}$ & 100 & 110 & 120 & 130 & 140 & 155 \\
\hline
\end{tabular}

Developing the production and application of aerated concretes can substantially decrease the cost, labor and energy intensity of construction while increasing the longevity, quality and environmental friendliness of houses in the severe and diverse conditions of nature and climate in Russia. The issues of increasing the efficiency of the production and use of aerated concretes can be solved through optimum characteristic highly porous materials obtained using composite binders. The use of the latter guarantees erecting energy-efficient buildings with sustainable performance.

Authorities in Russia are currently facing the issue of increasing the energy conservation in residential properties and building apartment complexes that are highly energy efficient and reduce energy requirements in both production and erection.

The recent increase of the investment potential of both separate enterprises and the population itself has led to the rise in demand for efficient wall materials.

The rise in demand is further facilitated by the increased requirements for heat transfer resistance in building structures, which necessitates the use of thermal insulation wall materials. This gave the rise to production of lightweight concretes, in particular the aerated concretes, including single-layer structures in high thermal resistance buildings, floor structures and external coverings in low-rise buildings, soundproofing of floors, walls, partitions, and in-situ casting. At the same time, the requirements to the performance characteristics of these concretes are also changing. First of all, this concerns the strength properties of structural thermal insulation concretes. There is a need to organize the process of monolithic construction from super-light thermal insulation concretes with the density of $120-300 \mathrm{~kg} / \mathrm{m}^{3}$ to replace the existing thermal insulation materials: mineral wool, styrofoam and similar materials, which have obvious shortcomings. This is why foam concretes have now gained a broad use in various areas of modern building industry, which was conditioned by the specifics of their porous structure and, accordingly, the wide variety of their functional applications [9-11].

Foam concrete is a type of aerated concrete, characterized by the presence of a large number of artificially created closed pores in the shape of spherical cells filled with air or vapor-air mixture. Fine air cells $0.5-3 \mathrm{~mm}$ in size are uniformly distributed across the volume of the concrete with thin and strong barriers between them that form the bearing space frame of the material.
In manufacturing aerated concretes at the current stage of development of small and medium-sized businesses, there is a demand for the non-autoclaved concrete technology, the advantages of which are low capital intensity and cost of production. Currently, non-autoclaved aerated concrete does not find due application because of the unavailability of the structure formation process management principles to ensure the high performance properties of the composite. Use of efficient foam concretes in monolithic casting technology allows to design and erect buildings that are attractive both in their spatial design and appearance, at the same time meeting the requirements to heat technology and strength. Monolithic construction allows to reduce consumption of materials and increase the reliability of modern buildings.

Use of foam concrete is the most economical and the easiest way of increasing a building's energy efficiency by increasing the thermal resistance of its envelope (walls).

Foam concrete was invented in in the early 20th century and became widespread in the thirties in the Nordic countries, the USA, China and Russia as a thermal insulation and structural material. However, its popularity soon declined with the appearance of autoclaved aerated concrete that had higher performance properties. At the turn of the century, when requirements to exterior walls became significantly stricter, aerated concrete with the density of $600-700 \mathrm{~kg} / \mathrm{m}^{3}$ proved to be less efficient in single-layer building envelopes compared with multi-layered walls. For an autoclaved aerated concrete wall to comply with the new building regulations, its thickness in the Russian climate must be increased twice: up to 1 meter. It is possible to ensure the required resistance of a single-layer wall's structure without increasing its thickness by decreasing the density of aerated concrete down to $400-500 \mathrm{~kg} / \mathrm{m}^{3}$ (while retaining its strength), which was already implemented in a number of developed countries with strict requirements to thermal insulation.

An adequate alternative to aerated concrete is the foam concrete produced using a cheaper and less energy-intensive out-of-autoclave technology. Foam concrete is a structural thermal insulation material that is obtained by introducing special foam into the concrete mass. After curing, its structure is porous. Foam concrete's properties vary significantly depending on its density.

The higher the density, the the higher are its strength, structural capabilities, but its thermal conductivity also increases. With the density of $400 \mathrm{~kg} / \mathrm{m}^{3}$, its thermal conductivity is $0.1 \mathrm{~W} / \mathrm{mK}$. With the density of $600 \mathrm{~kg} / \mathrm{m}^{3}$, it is $0.14 \mathrm{~W} / \mathrm{mK}$, with $800 \mathrm{~kg} / \mathrm{m}^{3}-0.21 \mathrm{~W} / \mathrm{mK}$, with $1000 \mathrm{~kg} / \mathrm{m}^{3}$ $0.29 \mathrm{~W} / \mathrm{mK}$, and with $1200 \mathrm{~kg} / \mathrm{m}^{3}-0.38 \mathrm{~W} / \mathrm{mK}$. For reference, the thermal conductivity of wood is $0.15-0.21$ $\mathrm{W} / \mathrm{mK}$, for high-density concrete, it is $1.68 \mathrm{~W} / \mathrm{mK}$, and that of geofoam is $0.046 \mathrm{~W} / \mathrm{mK}$. This is why foam concrete of different density can be used in virtually all elements of a house, from foundation blocks to flat thermal insulation roofs. Most commonly, foam concrete is used to produce masonry blocks (190x200x390 mm) and components of partition walls 
$(600 \times 300 \times 80 \mathrm{~mm})$ that are used in building pre-fabricated low-rise houses with framed structure.

Today, an increasing number of both builders and consumers are trying to learn more about this material and use it.

Foam concrete is currently one of the most demanded materials in individual building. Even though it appeared on the market a relatively long time ago, only in the recent years it actually gained consumer demand. This was mostly caused by the improvements introduced in the foam concrete production process, so now no property developer can imagine building a site without this material.

This increased demand for this material can be easily explained: foam concrete has sufficient strength, does not require additional thermal insulation, is weather resistant, is very soundproof and highly economical in production and use. Given its large size, it is lightweight and can be easily laid individually. Size error is very small in foam concrete blocks (no more than 1-2 $\mathrm{mm}$ is allowed), which makes it possible to lay them on a special glue solution, which in addition forms "cold bridges".

Large development businesses use foam concrete particularly because of its thermal insulation properties, because using foam concrete blocks as heat insulators is much more cost-effective than using any other insulation materials. Another advantage is that veneering a facade with foam concrete blocks does not require implementing any additional facade protection, since the material is resistant to temperature change, sunlight, and high humidity.

Building a house or another building, laying foundation, or erecting walls or partitions using such blocks is as easy as an erector set. Large foam concrete blocks are easy to work with: they can be cut and sawed to assume any required shape or lay cables.

The technology of foam concrete production is simple and at the same time interesting. This material is produced by uniform distribution of air bubbles across the whole mass of concrete. This process is carried out by mechanical mixing specially prepared (using foaming agents) foam with concrete mix that contains cement, water, and, frequently, sand. Unlike, for example, the autoclaved aerated concrete, there are no active chemical processes in this case.

All one can say is that foam concrete has a bright future. The demand for it is going to rise with each year, which will in turn lead new suppliers to the market and bring about further development of the businesses that manufacture this material. Presently, foam concrete, as a whole-mineral material with a range of outstanding properties, offers serious competition to a number of other traditional building materials. There appears the need to improve the qualities of this material to meet all demands of the building market.

\section{MAIN PART}

To carry out this research, raw amterials were selected according to their availability, technological properties and economic factors that positively affect the quality and cost of the final product. The work involved domestically produced binders, industrial fillers, and various functional additives:

1. TsEM I $42.5 \mathrm{~N}$ Portland cement, produced by the Voronezh branch of Eurocement Group.

2. Tailings of wet magnetic separation (WMS) of jaspilites from Stoilensky GOK.

3. Additives: Muroplast hyperplasticizer, PB-Formula 2012 foaming agent.

The experiment was carried out in two main stages: 1 . Design of the composition of composite binders for foam concrete; 2. Obtaining foam concrete based on composite binders.

1. Design of the composition of composite binders.

Special requirements are applied to the quality of a foam concrete binder: 1 . High dispersity;

\section{Low water requirement;}

\section{High strength.}

These qualities are found in the low water requirement binder (LWRB), a binder produced by grinding cement with the addition of hyperplasticizer in the proportion of $0.2-2 \%$. The significant difference of LWRBs from Portland Cements lies in their high dispersity, high strength (up to $100 \mathrm{MPa}$ ), and low water requirement due to optimum content of highperformance modifier introduced during intergrinding of all components.

Use of LWRBs in this technology leads to, on the one hand, saving cement, and on the other hand, increasing its compressive strength. Improvement of physical and mechanical properties of LWRB-based foam concretes is explained by the increase in their structural parameters. It was identified that cement rock and concrete produced using LWRBs have relatively low porosity and contain virtually no large capillary pores. The structure of LWRB-based cement rock has significant differences from the rock based on common Portland cement, which consists in the significant decrease of the overall number of pores and absence of large capillary pores and air bubbles. Consequently, the type of a cement rock's pore structure first of all predetermines its strength. This is the consequence of a low water-cement ratio. Use of LWRBs together with chemical additives allows to adjust the time of plastic strength increase in foam concrete in a broad range.

Composite binders with added WMS tailings were obtained in two stages:

1. Obtaining LWRB-100 by intergrinding cement with hyperplasticizer. 
2. Introduction of WMS tailings with different specific surface areas (SSA) into LWRB-100.

The reference binder (the object of comparison) was obtain by introducing WMS tailings with different SSA into Portland cement with the original dispersity. WMS tailings are ground separately until the SSA values reach 300,500 , and 700 $\mathrm{m}^{2} / \mathrm{kg}$.

LWRBs were obtained by grinding in a jar mill during $15-$ 20 minutes until the SSA of $550 \mathrm{~m}^{2} / \mathrm{kg}$. The gauging of WMS tailings was $1,3,5$, and $7 \%$ of the mass of cement. The watercement $(\mathrm{W} / \mathrm{C})$ ratio during mixing the binder paste with water was recorded. After thorough mixing, binder paste was placed in metallic molds with cells shaped as cubes sized $3 \times 3 \times 3 \mathrm{~cm}$. Samples were removed from the molds after one day of curing in natural conditions.

Further, they were subjected to steam curing in a laboratory steam curing room with the temperature of $90^{\circ} \mathrm{C}$ for six hours. After steam curing, the samples were dried in a drying chamber until reaching constant mass (to avoid the effect of the moisture factor on the results). dried samples were measured for their density and strength values.

The highest mechanical strength was displayed by the samples, which composition included WMS tailings (TWMS) with the SSA of $300 \mathrm{~m}^{2} / \mathrm{kg}: 7 \%$ wt. and with the SSA of 500 $\mathrm{m}^{2} / \mathrm{kg}: 3 \% \mathrm{wt}$. The development of their strength compared to the samples based on pure Portland cement amounted to 54$56 \%$.

The results demonstrated that tailings of wet magnetic separation of jaspilites modified the base LWRB-100, thus improving its physical and mechanical properties. These compositions were further used to obtain structural thermal insulation concrete.

2. Obtaining foam concrete on the base of selected compositions of composite binders.

Foam concrete samples were obtained using the following technology:

1. Binder components were thoroughly dry-mixed;

2. Foam was allowed to rise in the mixer during one minute;

3. In the course of three minutes, dry binder was introduced into the foam in small portions for maximum uniformity of its distribution and to avoid its sedimentation on the bottom of the mixer;

4. Foam-concrete mix was poured into cube molds with the edge length of $7.07 \mathrm{~cm}$.

After that, samples were processed in a steam curing room (according to the procedure of the previous experiment), then in the drying chamber. Then, samples were measured for linear dimensions and mass. Further, their strength was measured using a hydraulic press. Results of the experiments are shown in Table II.
TABLE II. RESULTS OF STUDYING FOAM CONCRETE SAMPLES

\begin{tabular}{|l|l|l|l|}
\hline $\begin{array}{l}\text { Composition } \\
\text { No. }\end{array}$ & $\begin{array}{l}\text { Binder } \\
\text { composition }\end{array}$ & $\begin{array}{c}\text { Density, } \\
\mathbf{k g} / \mathbf{m}^{\mathbf{3}}\end{array}$ & $\begin{array}{l}\text { Compressive } \\
\text { strength, } \mathbf{M P a}\end{array}$ \\
\hline 1 & LWRB-100 & 373 & 1.55 \\
\hline 2 & $\begin{array}{l}\text { LWRB-100+7\% } \\
\text { TWMS-300 }\end{array}$ & 433 & 2.55 \\
\hline 3 & $\begin{array}{l}\text { LWRB-100+3\% } \\
\text { TWMS-500 }\end{array}$ & 432 & 3.55 \\
\hline
\end{tabular}

In this experiment, the $\mathrm{W} / \mathrm{C}$ ration was assumed to be 0.33 , foaming agent content (equivalent to dry substance) comprised $1 \%$ of the binder mass, the water to foam ratio was 70:30.

Proceeding from the obtained data, a conclusion was made that the best parameters were displayed by composition \#3, since it displayed the highest strength.

Study of the microstructure of foam concrete samples were carried out using MIRA 3 LM high-resolution electron microscope. Images are shown in Fig. 1.

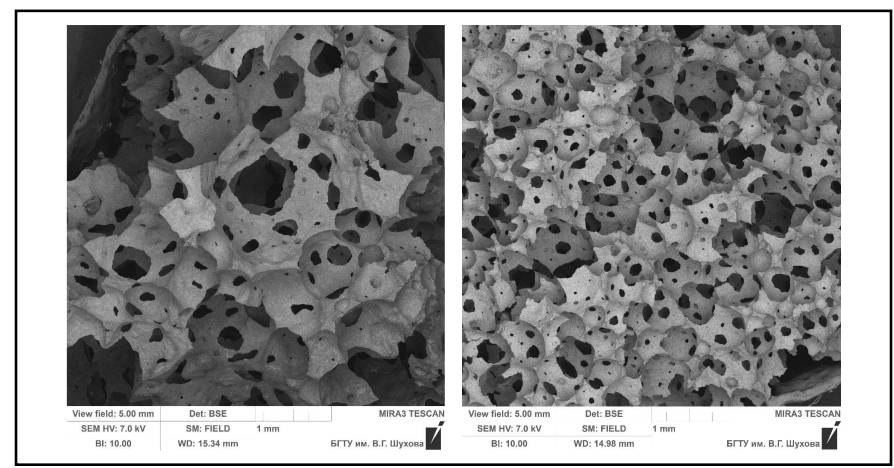

Fig. 1. Pore structure of foam concrete samples: reference (left) and composition No. 3 (right)

Fig. 1 shows the general pore structure of the samples with compositions 1 and 3 . It should be noted that sample 1 (reference) contains the jagged pore structure with a wide scatter of pore size. Also, sample 1 has a small number of pores per unit of volume. This is characterized by the large size of the distributed pores. These characteristics explain the low strength of the sample.

The pore structure of sample 3 is characterized by a higher amount of pores compared with sample 1, pore distribution is more uniform and size scatter is lower. Consequently, the foam concrete structure is more even and stable. Because of this, it can resist load with more efficiency and thus has a higher strength.

\section{SUMMARY}

In manufacturing aerated concretes at the current stage of development of small and medium-sized businesses, there is a demand for the non-autoclaved concrete technology, the advantages of which are low capital intensity, energy consumption, and cost of production. At the moment, foam concrete is a material with unique properties that successfully competes with many traditional building materials. There is 
the need to improve the qualities of this material in order to meet all demands of construction businesses.

To manufacture high-performance foam concretes, it is advised to use finely-dispersed cements that facilitate the stabilization of foam-concrete mix, accelerate the process of its curing, and allow to produce foam concretes of D300 grade and lower.

Works of a number of researchers indicate the high efficiency of replacing traditional cements with LWRBs, which in combination with chemical additives allow one to adjust the time of plastic strength development and other properties of foam concrete with a high degree of freedom. This offers the possibility of developing new non-cutting technologies for obtaining high-quality foam concrete blocks.

The issue of obtaining foam concrete for energy-efficient building with the parallel increase of the concrete's physical and mechanical properties can be solved by using composite binders based on nano-cement with advanced morphology and particle surface properties, with modifiers and ultrafine fillers. Development of such binders offers a real opportunity to significantly decrease industrial unit costs of fuel and electric power, to increase production output, and to provide production of high-performance foam concretes with minimum investment. Efficiency in producing such binders can be achieved by using domestic high-performance industrial products.

\section{CONCLUSION}

1. Compositions of binders with high physical and mechanical parameters based on LWRB and tailings of wet magnetic separation of jaspilites were developed. The optimal content of TWMS for different values of specific surface area were determined.

2. The possibility of producing foam concrete based on binders that displayed the best physical and mechanical parameters was identified.

3. Foam concrete with the density of $430 \mathrm{~kg} / \mathrm{m}^{3}$ and the compressive strength of $3.55 \mathrm{MPa}$ was obtained on the basis of the composite binder developed in this research. These characteristics allow one to recommend the obtained compositions for practical implementation.

\section{Acknowledgment}

The research was carried out within the framework of the Development Program of the Base University on the basis of BSTU named after V. G. Shoukhov

\section{References}

[1] V.S. Bessmertnyj, V.S.Lesovik, V.P. Krokhin, O.V. Puchka, E.P. Nikiforova, "Reducing properties of argon upon plasma treatment of refractory nonmetallic materials," Steklo i Keramika, Issue 10, pp. 3032,2001 .
[2] V.S. Lesovik, O.V. Puchka, S.S. Vaisera. "Reduction of energy consumption of thermal insulation," International Journal of Applied Engineering Research,Volume 10, Issue 19, pp. 40599-40602, 2015.

[3] L.A. Suleymanova, V.S. Lesovik, K.A. Kara, M.V. Malyukova, K.A. Suleymanov, "Energy-efficient concretes for green construction," Research Journal of Applied Sciences, Volume 9, Issue 12, pp. 10871090, 2014.

[4] A. Lagoaz, P. Szymanski, P. Walczak, "Influence of thefly ash propezti of autoclaved aezated concrete," $5^{\circ}$ International Conference on Autoclaved Aerated Concrete "Securing a sustainable future" to be held at Bydgoszcz to celebrate 60 years of AAC experience in Poland , 14-17 September 2011. University of Technology and Life Sciences, pp. 138144.

[5] D. Aldridge, Introduction to Foamed Concrete What, Why, and How Use of Foamed Concrete in Construction, London: Thomas Telford, 2005, pp. 1-14.

[6] Van Deijk, Foam concrete. Concrete, July/August 1991, pp. 49-54.

[7] J. Sach, H. Seifert, "Foamed concrete technology: possibilities for thermal insulation at high temperatures," CFI Forum of Technology, DKG 76, No. 9, pp. 23-30, 1999.

[8] M. Jones. Z.L. Roderick, "Energy-absorbtion of foamed concrete from low velocity impacts," Magazine of Concrete Research, 2013, 65 (4), pp. 209-219, 2013.

[9] E.P. Kearsley, P. J. Wainwright, "The effect of porosity on the strength of foamed concrete," Journal of Cement \& Concrete Research, №32, pp. $233-239,2002$.

[10] E.P. Kearsley, P.J. Wainwright, "Porosity and permeability of foamed concrete," Journal of Cement \& Concrete Research, №31, pp. 805-812, 2000.

[11] K.J. Byun, H.W. Song, S.S. Park, Development of Structural Lightweight Foamed Concrete Using Polymer Foam Agent, ICPIC, pp.98-99, 1988. 